\title{
BIOPHILIC INTERIOR DESIGN: A CASE STUDY ON THE RELATION BETWEEN WATER ELEMENTS AND WELL-BEING OF THE USERS IN AN EDUCATIONAL BUILDING
}

\author{
Fiona NEVZATi* \\ Prof. Dr. Ö. Osman DEMIRBAȘ * * \\ Prof. Dr. Deniz HASIRCI***
}

\begin{abstract}
The concept of biophilia is an innate human tendency to seek connection with nature. Biophilic design is the integration of the built environment and nature, which offers an opportunity to design healthier places, resulting in lower stress and improved well-being. Water elements are considered one of the most effective biophilic design elements for the betterment of the interiors through decreased stress and improved mood. This paper examines the relationships between well-being and principles of biophilic design through indoor water elements, with specific focus on educational environments. A case study was conducted examining the effects of various indoor water elements for an entrance area of an educational building. It was found that occupants were generally content with the presence of interior water elements, and they perceived that direct access to nature made them feel more connected with it. There is a statistically significant difference between the responses of males and females, $\mathrm{t}=-2.041, \mathrm{p}=0.045(\mathrm{p}<0.05)$, while females perceived lowered stress when in the presence of interior water elements, males were more neutral. The research study concludes with a discussion on the means by which interior water elements can reduce stress and increase relaxation.
\end{abstract}

Keywords: Biophilic Design, Interior Architecture, Interior Water Elements, Educational Environments, Well-Being

\footnotetext{
*Estonian University of Life Sciences, Institute of Agricultural and Environmental Sciences, Dept. Landscape Architecture, Tartu, Estonia, fionanevzati@emu.ee, 0RCID: 0000-0003-1124-7407

** Izmir University of Economics, FFAD, Dept. Interior Architecture and Environmental Design, Izmir, Turkey, osman.demirbas@ieu.edu.tr, ORCID: 0000-0002-8279-2157

*** Izmir University of Economics, FFAD, Dept. Interior Architecture and Environmental Design, Izmir, Turkey,, deniz.hasirci@ieu.edu.tr, ORCID: 0000-0001-9928-6077
} 


\title{
BiYOFiLIK ic MEKAN TASARIMI: BIR EĞiTiM BINASINDA SU ÖĞESI KULĹANIMI ILE KULLANICI REFAH SEVIYYSi ARASINDAKi ILIȘKi ÜZERINE BíR ALAN C̣ALIȘMASI
}

\author{
Fiona NEVZATi * \\ Prof. Dr. Ö. Osman DEMIRBAȘ * * \\ Prof. Dr. Deniz HASIRCI ***
}

Özet: Biyofili kavramı, insanların doğuştan gelen doğa ile bağlantı kurma eğilimidir. Biyofilik tasarım ise sağlıklı mekanlar tasarlama fırsatı sunan, daha düşük stres ve gelişmiş refah sağlayan, yapılı çevre ve doğanın bütünleşmesidir. Su öğeleri, stresin azalması ve ruh halinin iyileştirilmesi yoluyla iç mekanların geliştirilmesi için en etkili biyofilik tasarım unsurlarından biri olarak kabul edilir. Bu makale, eğitim ortamlarına özel olarak odaklanarak, iç mekan su özellikleri aracılığıyla sağlık ve biyofilik tasarım ilkeleri arasındaki ilişkileri incelemektedir. Bir eğitim binasının giriş alanı için çeşitli iç mekan su özelliklerinin etkilerini inceleyen bir vaka çalışması yapılmıştır. Çalışmada, bina sakinlerinin genellikle iç mekan su unsurlarının varlığından memnun olduğu ve doğaya doğrudan erişimin kendilerini onunla daha bağlantılı hissetmelerini sağladığı tespit edilmiştir. Erkeklerin ve kadınların tepkileri arasında istatistiksel olarak anlamlı bir fark olarak, kadınların iç mekanda su unsurları kullanıldığı zaman daha az stres algıladıkları, erkeklerde ise bu durumun daha daha nötr olduğu saptanmıştır ( $t=-2.041, p=0.045, p<0.05$ ). Çalışmanın sonuçları, iç mekanlarda su öğelerinin kullanımının stresi azalttığı ve rahatlamayı artırdığı göstermektedir.

Anahtar Kelimeler: Biyofilik Tasarım, İçmimarlık, İç Mekan Su Öğeleri, Eğitim Çevreleri, Refah

Geliş Tarihi: 17.12.2020 Kabul Tarihi: 10.02.2021 Makale Türü: Araştırma Makalesi

\footnotetext{
*Estonya Yaşam Bilimleri Üniversitesi, Tarım ve Çevre Bilimleri Enstitüsü, Peyzaj Mimarlığı Bölümü, Tartu, Estonia, fionanevzati@emu.ee ORCID: 0000-0003-1124-7407

**izmir Ekonomi Üniversitesi, GSTF, İçmimarlık ve Çevre Tasarımı Bölümü, İzmir, Türkiye, osman.demirbas@ieu.edu.tr, ORCID: 0000-0002-8279-2157

*** İzmir Ekonomi Üniversitesi, GSTF, İ̧mimarlık ve Çevre Tasarımı Bölümü, İzmir, Türkiye, deniz.hasirci@ieu.edu.tr, ORCID: 0000-0001-9928-6077
} 


\section{INTRODUCTION}

As a common ancient notion, human beings' exposure to nature is considered to have positive effects on their psychological health, and therefore, it is feasible to create an environment that stimulates well-being by using restorative methods that improve mood and increase mental vitality, thus reducing fatigue. Contact with water, plants and other natural elements can calm anxiety and help people more easily cope with stress (Ulrich, 1979; Kellert, 2005). The concept of biophilia, introduced by Wilson as the "urge to affiliate with nature", explains the human action, need, appreciation, and great satisfaction that comes from nature, whether directly or indirectly (Wilson, 1984).3 Biophilia is defined as the inbuilt need to connect to nature and living things, to improve physical and mental health and wellbeing (Kellert, 2005, 2014; Kellert and Wilson, 1993; Ulrich, 1992; Demirbaş and Demirbaş, 2019). On the subject of the connection between people and the built environment, nature has long been of particular significance to humans' well-being and positive state of mind; however, today it has lost much of its value (Kellert, 2005).

Biophilic design is a way of designing environments that encourage people to reunite with nature (Tarakçı Eren et al., 2018). It is important because it gives opportunities for healthier living and workplaces, with decreased levels of stress, added well-being, and improved mental health. Applying biophilic design approaches in workplaces, healthcare facilities, schools, and surroundings are known to benefit worldwide health, and the global economy (Kellert, 2005; Browning et al., 2014).

Previous research on the benefits of biophilic approach in interior design reports the improvement of many aspects including physical health, blood pressure, mood, work satisfaction, creativity, motivation, b concentration, and enriched social interaction as well as a decreased risk of diseases (Ulrich, 1992; Kellert and Calabrese, 2015; Annerstedt and Währborg, 2011; Ulrich, 2008, 1993; Wells and Rollings, 2012). Biophilia focuses attention on the innate human need for contact with nature and adaptations to the natural world, over the course of evolution, and its effect on physical and mental health and well-being through harmonizing buildings with plant life (potted plants or trees), allowing panoramas of nature, and maintaining exterior vegetation (e.g.: "green roofs"). The second strategy suggests implementing vegetation in architecture by mimicking the natural elements through three approaches:

1.Combining approximately identical vegetative imitations in architecture design (for ex: plantbased ornaments);

2.Mimicking nature in architecture in an artistic and abstract way. This method is known to provoke Biophilic responses in the human mind, which interprets these frames as a mirror of nature itself. A good example is the interior of Gaudi’s Sagrada Familia with the stylized columns of forest-like trees.

3.Copying minor visual characteristics of nature in architecture, such as fractal characteristics. According to some Biophilic design theorists, a three-dimensional architecture with fractal elements are most likely to evoke biophilic reactions. Accordingly, the cases of Gothic and Hindu temples are preeminent models of fractal architecture (Joye, 2011).

Apart from the constructional aspects of built environments, researchers have discovered that worker performance, well-being and comfort have been influenced by access to nature, and developed theories that explain why contact with nature is considered to be a benefit for workers. From the viewpoint of attention restoration theory (Felsten, 2009), interiors with natural features represent restorative environments due 
to their power to attract attention and imbue a sense of calmness and recovery. Even a brief instance of relaxation, such as looking out the window at a tree, or at a plant indoors, is capable of providing what Kaplan refers to as microrestorative experiences (Mangone et al., 2017). Biophilic strategies are known to deliver a healthy, natural atmosphere to an office, which improves collaboration and productivity. Greenery and nature imagery bring extra advantages, but there should be a studied way of using it in the design process. Heerwagen and Orians (1986) have found that people in offices without windows often used images of nature, including murals. Ulrich's (1992) study shows that bed-ridden patients exposed to tranquil pictures including water or other nature scenes have shown a better recovery process than those exposed to random pictures or no pictures at all.

iophilic design refers to the integration of this appreciation and the design of the built environment, and the sense of fulfillment from contact with nature in the built environment is known as "positive environmental impact" or "biophilic design" (Ulrich, 1992). Thus, there are two basic dimensions of the biophilic design: organic design and vernacular design. These refer to the use of shapes and forms in the built environments or sites that, directly or indirectly, provoke' inborn attraction to the natural world. The effects of Organic design are seen in practices such as the use of natural lighting, ventilation, and materials; in the presence of water and vegetation; and decoration and ornamentation mimicking natural forms and processes. In contrast, vernacular design refers to the buildings and landscapes that nurture a link to places through the connection to culture, history, and ecology (Kellert, 2005). Biophilia is biologically encoded because it verifies physical, emotional, and intellectual health development during the process of evolution. Therefore, the' necessity for contact with nature reveals the reality of human evolution in nature, as opposed to an artificial or constructed world. Put differently, the background of human evolution regarding the human mind and body originates from a sensory world led through an environment structured by light, sound, odor, wind, weather, water, vegetation, animals, and landscapes. The development over the last 5,000 years of extensive industries, technology, and mass production, engineering and the modern city represents a very limited period of human history, which until then had been dominated by the natural environment (Kellert, 2005). However, any biophilic explanation for human behaviors must also recognize that as the dominant habitat of humanity, cities should be regarded as 'ecological', and' not merely socio-cultural entities (Byrne, 2011).

Low-environmental-impact design has resulted in surprisingly little net benefit to productivity, health, and well-being; biophilic design is thus viewed largely as the missing link in prevailing approaches to sustainable design. The integration of low-environmental-impact and biophilic design must therefore, achieve a complementary relation for true and lasting sustainability (Kellert, 2005).

Browning et al. (2014) propose a combination of 14 patterns as an extra tool in the designer's toolkit aimed at the integration of the built and natural environments. Consequently, each of these biophilic design patterns can influence space, creating different designs. In the last two decades, the study of biophilic design has developed rapidly and as a consequence, it is likely that some patterns will be supported more than others, but, new patterns will always occur, due to a growing research interest in biophilia. From a spatial point of view, biophilic design patterns shift the designer's perspective towards the connection between people, health, highperformance design and aesthetics (Demirbaş 
and Demirbaş, 2019; Browning et al., 2014).

In order to avoid misinterpretation of the biophilic design in an environment, Joye (2011)

offers two possible strategies for people to experience the effect of biophilic design. The first strategy suggests that people experience nature, for example, greenery, in architecture. Environmental stress has both negative psychological and physiological effects, and is one of the most challenging user experiences in a public building (Baum et al., 1984; Bilotta et al., 2019; Bhat, 2015). Especially in an educational building, it is very important, as stress will affect the learning experience and health of the occupants (Mangone et al., 2017; Baum et al., 1984). Students' constant struggle with mental fatigue, stress, loss of attention, and their drained mental state is partly because of ambient stressors, among various other environmental stressors in public interiors (Watchman et al., 2020; Evans and Cohen, 1987). Ambient stressors can easily be eliminated through careful interior design (Freihoefer et al., 2013). Nature is known as one of the most effective factors for the refreshment of those who are extremely focused on their work, and contact with nature, as suggested, has an ability to refresh psychological conditions through experiencing particular environment (Joye and van den Berg, 2019). Students are also often threatened by stress during their academic life as a reaction to the imbalance between the circumstances and their own capacity (Steg et al., 2019). According to Ulrich, constant exposure to stress can have consequences on the physical health, and cause risk of disease (Ulrich, 1986). Therefore, it is beneficial and important for students' mental health and well-being to find places where they are refreshed and cognitively revitalized through their connection with nature, and thus, can continue their work (White et al., 2010).

Apart from the daily usage of water, existence of water in the built environment as a spatial design element or an art installation influences aesthetics, noise pollution, humidity and thus, the mood (Düzenli et al., 2019; Bilir, A., 2019). Although, hydrotherapy that is defined as a cure through water, has been used as a method for the treatment of various illnesses in history; today, with the advancement of life that brings an increasing demand, the contemporary world is facing a shortage of clean water, which itself can cause health problems (Heerwagen and Orians, 1986). Applying water elements in interiors using biophilic design approaches is definitely not a solution for clean water shortage however it may lead to the improvement of the occupants' well-being. Furthermore, using biophilic design strategies through water elements has an important role in creating sustainable, inspiring, and cost-effective environments for human habitation (Kellert, Heerwagen and Mador, 2011). Additionally, studies have shown that water brings value, as houses and hotel rooms that have a direct view of landscapes including water (Luttik, 2000; Lange and Schaeffer, 2001) have greater financial worth, and people favor interiors that include water elements (Kaplan and Kaplan, 1989).

This paper similarly focuses on the positive outcomes of biophilic design in a built environment through a case study that is aiming to understand the user contentment and preferences of interior water elements in the entrance area of an educational building. The main objectives are; to understand user reactions and preferences about interior water elements, to find out if there are any positive effects of indoor water elements on daily stress factors and to find if there is any preference difference of interior water elements according to gender. In order to achieve these goals, a questionnaire-based survey was applied to the daily users of the selected public area. 


\section{METHODOLOGY}

This study hypothesizes that, depending on the preferences of the occupants, applying water elements in interiors using biophilic design approaches will lead to the improvement of their well-being. Applying biophilic approaches using the water elements expands the chances of creating stimulating, sustaining, inspiring and cost-effective environments for human habitation (Annerstedt and Währborg, 2011). It entails understanding the reasons for preferences for interior water elements, and recognizing the feelings of participants when in the presence of water elements, as a biophilic design element. The existence of an interior water element is considered to promote the well-being of the students constantly exposed to stress and intensive study during their academic year, leading to mental fatigue. Mental fatigue occurs when the brain is experiencing continuous mental effort, which may undermine academic success. Consequently, in an atmosphere of stress and mental fatigue, applying interior water elements in everyday spaces may improve mental health and well-being.

It is beneficial for the mental balance and stability of the students to find places on their campus where they can experience mental restoration, and continue their work cognitively revitalized. Transient spaces such as entrance and lobby spaces of these kinds of public buildings have a crucial role in creating the desired atmosphere (Rutkin, 2005). These spaces are connecting the outdoors with the indoors, a friendly entrance and lobby area of a public building will evoke a welcoming feeling (Tanner, 2000). Today, transitional spaces in higher education buildings are considered to be an efficient behavior setting that offers a possible space for better interaction of the users. Better utilization of these spaces will help to enhance the overall performance of the educational buildings (Nassar and El-Samaty, 2014). Inclusion of ecological approaches and sustainability issues in the design and/or refurbishment of the transient spaces have considerable influence on behavioral performance and wellbeing (Triantis, 2005). Recent research shows that biophilic interior design approaches like indoor gardens, interior water elements and the like are an efficient way of enhancing the overall performance of the transient spaces (Lau and Yang, 2009; Abercrombie et al., 1998; Toyne and Khan, 1998).

In this study, the research has been confined with the inclusion of interior water elements that are one of the 14 patterns of biophilic design (Browning et al., 2014). There are four different interior water elements proposed for the entrance of the FFAD building, to allow oncampus students to use these biophilic elements for mental nourishment. A questionnaire-based survey was conducted to understand their preferences regarding interior water elements. The participants familiar with the building were given the extended version of the survey, which comprised 3D visualizations for the proposal of the application of interior features in the building entrance. This survey extension was not given to the participants unfamiliar with the building. While familiarity was defined as continuous users of the building within a specific schedule, unfamiliarity was defined as only being visitors or using the building for a short amount of time that is not repeated.

\subsection{Research Questions}

Throughout this research project, three questions were addressed:

1. How do the occupants feel around interior water elements?

2. What is the relationship between interior water elements preferences and stress factors?

3. What are the differences in occupants' preferences for interior water elements according to gender? 


\subsection{Setting}

The location selected is the entrance lobby of the Faculty of Fine Arts and Design (FFAD) building at the Izmir University of Economics (IUE) in Balcova, Izmir, Turkey. As seen in Figures 1, 2 and 3, the lobby has no specific definition. Before the application, this space was transformed from a security guard station with a desk to a blank space used only as an exhibition platform for students' final presentations. The composition of this space, where the instruments were applied, is characterized by raw and an unfinished look, neutral tones, and lack of furniture, displaying the building materials and a redundant state with a plethora of wood and metal surfaces. The spatial organization seems to be unidentified, since this place has been in a rigid dichotomy with the surrounding elements, holding a long-
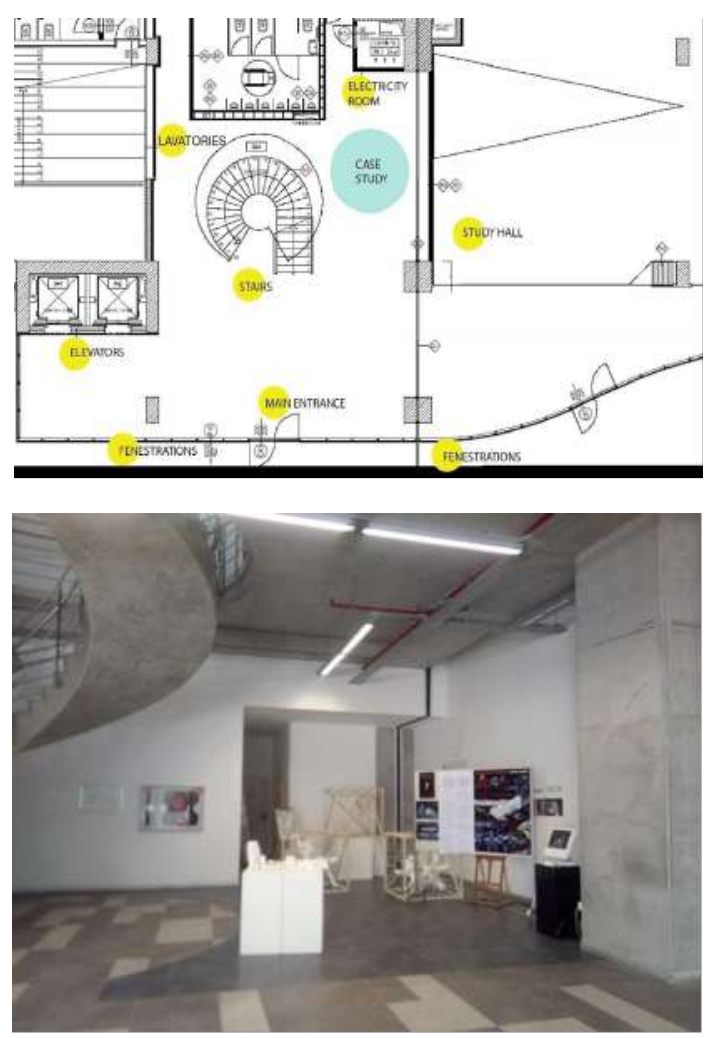

Figure 2. The lobby area of FFAD building term transient character. In order to balance the current detached and monolithic context of the space, the main aim of the research was to enrich this space with a touch of nature, and transform the current condition into an affirmation, without overpowering the space or destroying its character. Therefore, the composition of the space was envisioned so as to create equilibrium between the built (existing) and the natural (biophilic design) state, by observing its influences on the users' mental health.

This space is central to the vertical and horizontal circulation, including the main entrance, but rather than standing out as an eye-catching and welcoming extension of the FFAD building, this part is unfortunately currently merely a transitional space, despite its high potential to be an effective multi-functional interior space. In this respect, the application of biophilic

Figure 1. The plan of the existing lobby area of FFAD building

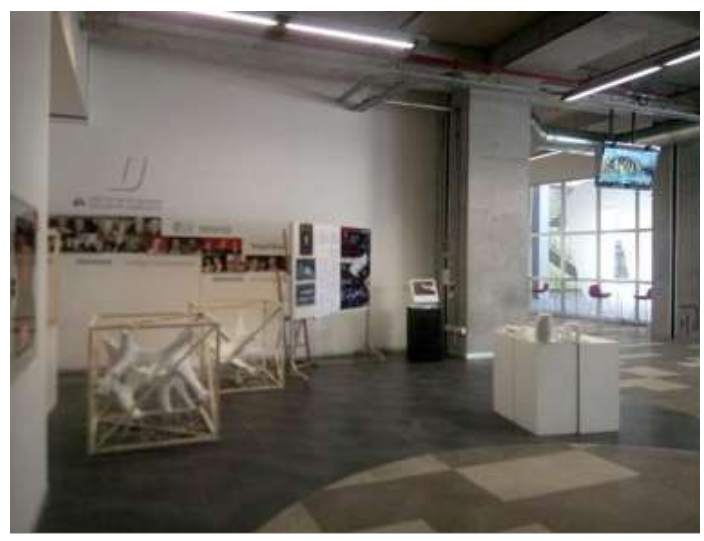

Figure 3. The entrance of FFAD building 
design elements of water has potential to change character of this valuable space. It is considered that installation of any interior water element in this area would improve its condition by buffering background noise, maintaining a cool and moist natural atmosphere, and improving the interior's aesthetic appearance. The sound of water is more favorable than other environmental sounds, arousing restorative and meditative states, which brings positive mental effects that can aid well-being and a positive state of mind (Kaplan and Kaplan, 1989). For these reasons, a new biophilic design concept for the entrance of the FFAD building was recommended. In the context of the study, proposals for four different types of interior water element installations were presented to the participants through nonimmersive 3D images. The selected four types
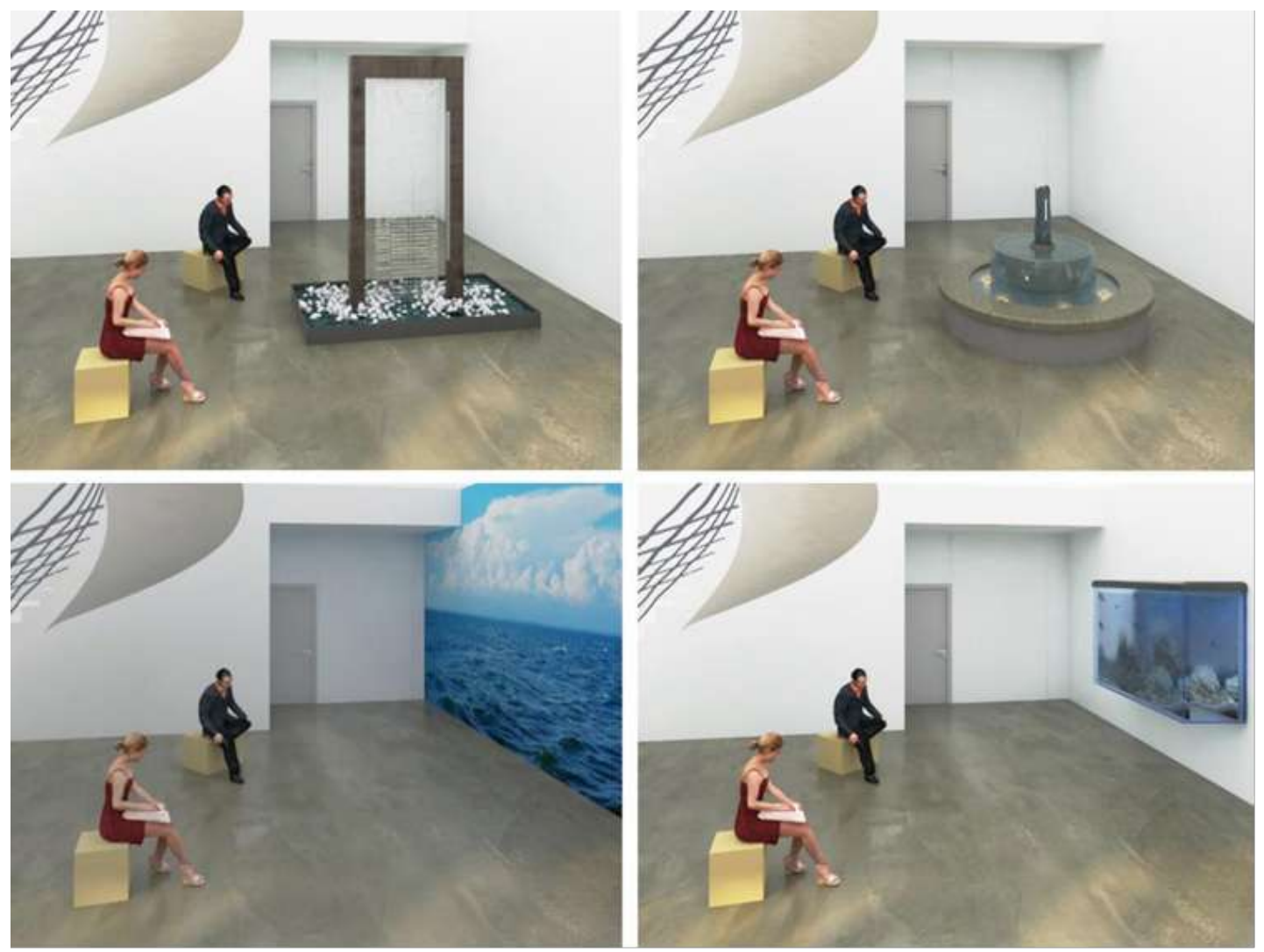

Figure 4. Interior water-wall installation proposal (left up), interior decorative fountain installation proposal (right up), ocean view wall surface installation proposal (left bottom), built-in aquarium proposal (right bottom) for the entrance lobby of FFAD of interior water elements are a water-wall, a fountain, an ocean view wall surface, and a builtin aquarium (Figure 4).

\subsection{Sample}

The study was conducted during the two-week final exam period of 2017-2018 Spring Semester. The final exam period was selected as the most stressful time of the year for the students. A mixture of simple random sampling and convenience sampling was used. Because of time limitations and the ever-changing population profile for the selected area, convenience sampling was the most practical solution. However, all of the participants were regular users of the building, so the selected sample was an acceptable representation of the whole population. 
In this respect, it was aimed to include at minimum $10 \%$ of the whole population. The sample size was 74, of which $63 \%$ were females, $33 \%$ were males and $4 \%$ declined to mention. $67 \%$ of the participants were students from design programs, and the remaining ones were students from different faculties who were taking classes from the design programs. These faculties included linguistics, computer sciences, economics, robotics, animal biotechnology, software engineering, business, political sciences, geodesy, law, marketing, mechanical engineering, sociology, and anthropology. The participant students were from different degree programs with an age range of 20 to 29 . The length of stay of the users in the selected area was between 5 minutes to 20 minutes according to the waiting time of the lifts or meeting with others. Since the selected lobby area was mostly an empty lobby space and used as a transient space, the length of stay was not considered as a factor for the existing study.

\subsection{Procedure}

The survey consists of two parts, the questionnaire, and non-immersive $3 \mathrm{D}$ virtual views of the selected space with the selected water elements (Figures 4, 5, 6, and 7). These nonimmersive $3 \mathrm{D}$ virtual views were used to visualize the proposed biophilic design for the entrance of the FFAD building.

First, the stress factor was evaluated through t-test analysis considering gender differences, and differences in educational background, i.e., design and non-design students. Secondly, the correlations between the presence of water elements in the interior and feeling of stress were tested through Pearson Correlation analysis. Finally, user attitudes toward the presence of water elements in the selected area were discussed in terms of the strength of the preferences for the different proposed water elements of the selected interior.

\section{RESULTS AND DISCUSSION}

Related to research questions concerning the relationship between interior water elements preferences and the stress factor, results show that participants feel less stressed when they encounter any water elements in closed environments. When asked about their preferences for interior water elements, the responses of females and males were very similar regarding the preference for water walls, fountains, waterfalls etc. over the second group, including fishponds and aquariums, and the third group, including water photographs, ocean views wallpapers, and water-themed paintings. As their second choice, males prefer fishponds and aquariums, and females, the visual group of interior water elements such as photographs, wallpaper, and water-themed paintings (Figure 5).

\subsection{Stress factors for college students}

According to the Independent t-test scores (Table 1), considering the grades as a stress factor there was a statistically significant difference between males and females, with males finding them more stressful t $(68)=2.069, \mathrm{p}=0.042(\mathrm{p}<0.05)$.

Participants were from different faculties, and clustered under two groups as 'designers' and 'non-designers'. This classification was rational because the main concern was the criterion as biophilic design, and the selected case study site was the Faculty of Fine Arts and Design building of IEU. It was found that there are statistically significant differences between the two groups regarding the level of stress from workload and time constraints factors. Independent t-test scores for workload are $\mathrm{t}(69)=2.115, \mathrm{p}=0.038$ $(\mathrm{p}<0.05)$, where t-test results for time constraints and deadlines are $\mathrm{t}(66)=3.619, \mathrm{p}=0.001$ $(\mathrm{p}<0.01)$. For both issues, designers showed higher stress levels than non-designers (Table 2). 




Figure 5. Interior water elements preferences according to gender

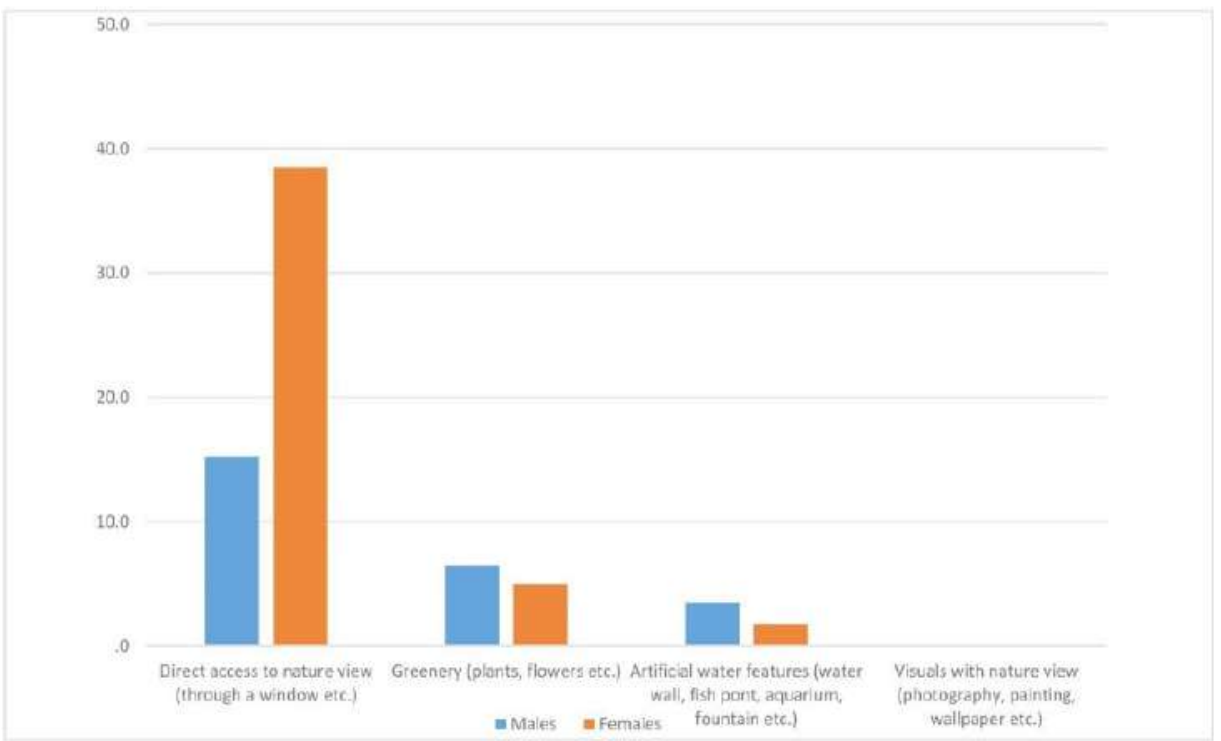

Figure 6. Being connected to nature preferences according to gender 


\begin{tabular}{lll} 
& $t$ & $\begin{array}{l}\text { Sig. } \\
\text { (2-tailed) }\end{array}$ \\
\hline academic process & 0.689 & 0.493 \\
grades & 2.069 & $0.042^{*}$ \\
classmates & 0.900 & 0.371 \\
exams/assignments & -0.121 & 0.904 \\
health & 0.671 & 0.505 \\
finance & -0.269 & 0.788 \\
workload & -1.995 & 0.050 \\
deadlines & -0.735 & 0.465 \\
\hline
\end{tabular}

Table 1. Independent t-test scores according to gender and stress factors

\begin{tabular}{lll} 
& $t$ & $\begin{array}{l}\text { Sig. } \\
\text { (2-tailed) }\end{array}$ \\
\hline academic process & 1.263 & 0.211 \\
grades & 1.361 & 0.178 \\
classmates & 1.604 & 0.113 \\
exams/assignments & 1.000 & 0.321 \\
health & 1.484 & 0.142 \\
finance & 1.291 & 0.201 \\
workload & 2.115 & $0.038^{*}$ \\
deadlines & 3.619 & $0.001^{* *}$ \\
\hline${ }^{*} p=0.05$ & &
\end{tabular}

Table 2. Independent t-test scores according to profession and stress (designer vs non-designer) 


\subsection{Pearson Correlations between stress factor and interior water entity preferences}

In order to reveal the correlations between participants' preferences and stress factors, Pearson Correlations tests were conducted (Figure 7). According to results, the individuals reporting feeling stressed due to general academic processes also stated that any water element in the built environment could be considered a good representation of nature $(\mathrm{r}=0.251, \mathrm{p}=$ 0.031 ). Negative correlations were found between the perception that water visuals (photographs, paintings, wallpaper) in the interior spaces were relaxing, and the perception that stress was caused by grades $(3.2, r=-0.251, \mathrm{p}=0.031)$ and assessment mediums (exams, assignments etc.,
$3.5, \mathrm{r}=-0.277, \mathrm{p}=0.017)$. According to these results, it could be interpreted that participants who experienced assessment-related stress denied that water visuals were a positive interior application helping them to feel more relaxed. An interesting result was the positive statistically significant correlation between the health factor for stress, and the perception that any interior water elements is a good representation of nature $(\mathrm{r}=0.329, \mathrm{p}=0.004)$. A possible interpretation is that these students, especially those feeling stressed because of possible health problems, felt healthier when closer to nature, and therefore, they found that water elements, as spatial elements were a good representation of nature in the built environment.

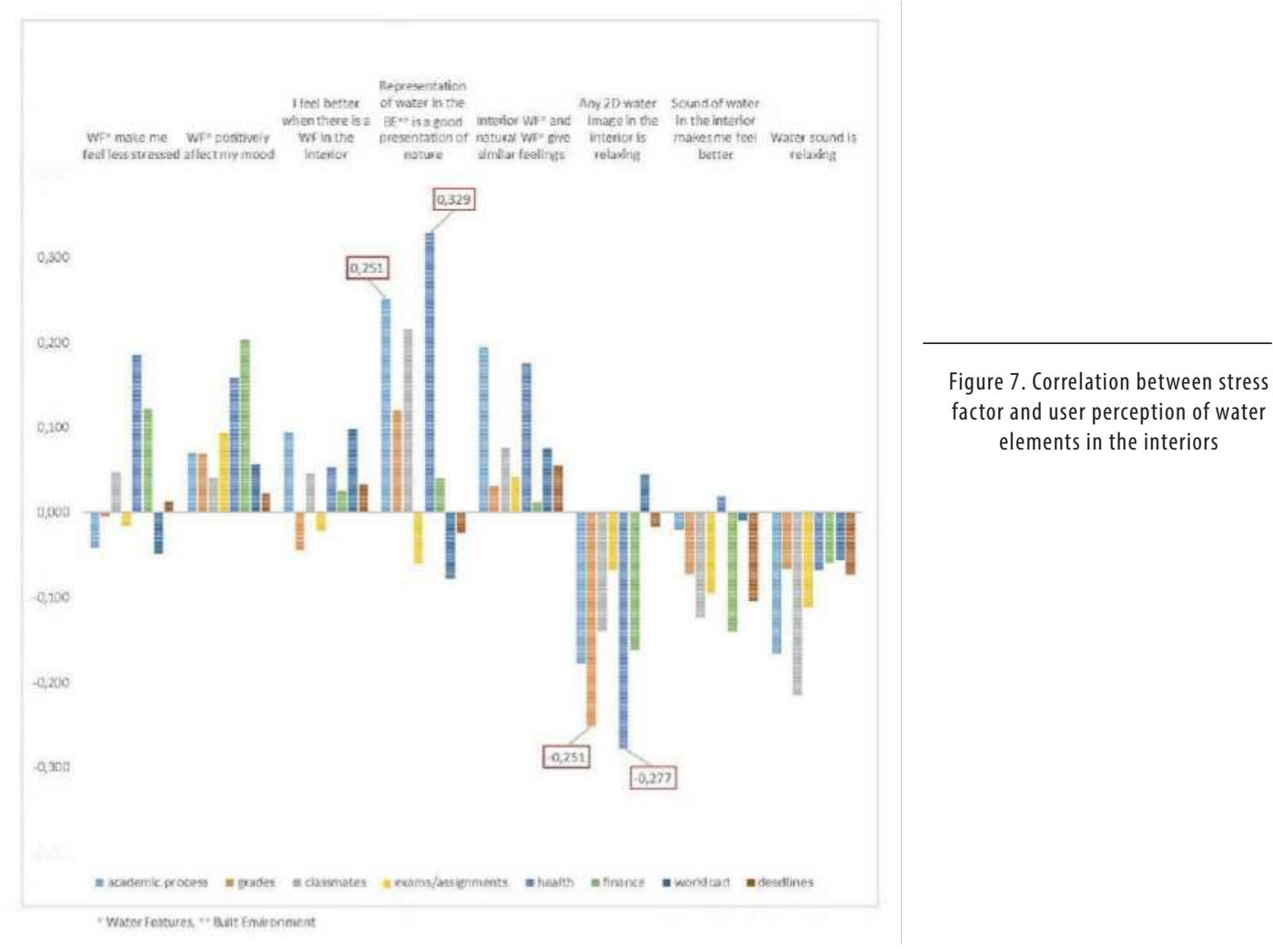


The overall findings of the survey show that the majority agreed on the positive effects of interior water elements, in line with the hypothesis that applying water elements in the interiors using biophilic design approaches may lead to improvements in the occupants' state of well-being. However, when indoors, $77 \%$ of participants, regardless of gender or any other specification, felt they were most connected to nature when having direct access to a view. These findings are consistent with Tennessen and Cimprich (1995) who compared college students with and without direct access to a view of nature from their dormitory. The study found that students exposed to a natural view scored higher on tests of direct attention than those who do not (Tennessen and Cimprich, 1995).

Regarding the previously mentioned research questions concerning the feelings of the participants around interior water elements, it is found that $70.4 \%$ of the participants reported that water elements help them feel better in times of stress, $74 \%$ reported that water elements positively affect their mood, and $57 \%$ reported that they feel better when in presence of interior water elements. To understand these results, it is important to realize that hearing and touching water, like seeing it, brings relaxing effects as well (Alvarsson et al., 2010). Browning et al. (2014) argue that nature images with water elements give higher expectations for lowering the blood pressure and heart rate compared to nature images without.

Participants did not noticeably relate real natural water elements such as lakes, waterfalls, and the sea to the artificial interior water elements such as fountains, aquariums, and waterfalls since $33.5 \%$ of the answers to this item were neutral, 27\% disagreed and $31 \%$ agreed. This might suggest that real natural features either awaken deeper and unique feelings on mental and physical states; alternatively, it may mean that real nature has the power to simultaneously arouse multiple senses, unlike artificial water elements. For example, a single installation of a water wall in a shopping mall merges with surrounding sounds including talking, footsteps, elevators and cash machines. They can also see the water motions, but have limited opportunity to touch with the fingers palm of the hand, and smell is dominated by the chemicals that keep the installation clean and hygienic. In contrast, in nature, real natural water elements, for example, a waterfall, has multiple levels of satisfaction for the senses, such as feeling the breeze or the sunshine after bathing, smelling mixed natural features of the surroundings, such as earth, flowers, grass, which combine to create the natural fragrance of water, which does not have a specific smell, but it usually absorbs other natural components. Other senses include the taste of natural spring water and hearing water splash and fall.

$71.6 \%$ of the participants found water sounds relaxing, and $66.3 \%$ Water found visuals such as photographs and paintings in the interior to be relaxing. Alvarsson et al. (2010) found that water sounds had meditative effects and combined sounds from a water fountain and bird song helped increase the physiological recovery of the nervous system. Whether placed at work, home, health facilities or educational facilities, sounds of gently flowing water bring a healing atmosphere (Clouse, 2016).

Almost 75\% of the participants were positive about the first two survey questions, but the third, the positive response percentage dropped by almost $15 \%$. This question elicits a more general feeling about the mood in the presence of interior water elements, whereas the first asks how they feel around interior water elements specifically when stressed. This question implies that the statements "feeling better" and "having a positive mood" have different meanings for respondents. Although the difference between the outcomes was not great (about 15\%), some of those who stated that artificial interior water elements 
made them feel better when stressed were more indecisive or even negative when asked if these elements had a more general positive effect as on their mood.

When asked to comment on their opinion for the improvement of the physical environment of the campus area to lower their stress level, $10 \%$ of participants mentioned nature sounds and the reduction of noise pollution on campus. In addition, $22.5 \%$ expressed a preference for nature, referring to fresh air, natural light, sunlight, warmer wall colours, and less use of bare concrete, and direct visual access to nature. $32.5 \%$ expressed a preference for water elements such as fountains, ponds, water visuals, water elements and sources, and $35 \%$, for indoor vegetation, such as plants, gardens, flowers and green walls. This might suggest that the participants understand the importance and benefits of contact with nature, and are seeking more sustainable and green places in their campus to relax, refresh themselves, and spend free time.

The findings from the 3D visualizations showed the water wall installation as more preferred, whereas one of the other applications had the same level of preferences as the ocean view wallpaper and the aquarium in the entrance of the FFAD building. Therefore, this might suggest that the water wall installation might be the optimal choice for increasing well-being and reducing stress.

\section{CONCLUSION}

Biophilia refers to humans' innate need for contact with nature, and their adaptations to the natural world through evolution, as a way of maintaining 'physical and mental health and well-being. Biophilic design is a way of designing an environment that invites people to reunite with nature. It is important because it gives the opportunity to live and work in healthier environments, with decreased levels of stress, increased well-being and improved mental health.
Among biophilic design applications, water appears to be one of the most effective, having a variety of uses in history for therapeutic as well as aesthetic purposes. Understanding the means by which water elements work may enable their utilization in a variety of environments. Higher educational environments carry significance on several layers in terms of using biophilic, and especially water elements.4,5 Water can be beneficial for students' mental health while spending substantial amounts of time on campus accomplishing tasks that require complete directed attention likely to cause attention fatigue.

The motivation for conducting this research was students' and workers' constant battle with mental fatigue, stress, loss of attention and drained mental state resulting from work and study. In addition, students often face stress during their academic life as a reaction to the imbalance of the difficult circumstances and their capacity to manage these, which have consequences for physical health, and can lead to disease (Watchman et al., 2020; Najafi et al., 2018).

This study hypothesized that applying water elements in the educational interiors using biophilic design approaches may lead to the improvement of the occupants' environment and thus, state of well-being. In the context of the built environment, nature is particularly of significance to the humans' well-being and positive state of mind, but unfortunately, has lost its value in contemporary times. 2 In contrast to the hypothesis, participants did not noticeably associate artificial interior water elements such as water walls, aquariums, and fountains with the real water elements such as lakes, fishponds, and seas. The results of this research study showed that interior water elements help in the reduction of stress, and provide an overall positive effect on emotional state and mood. However, participants' favored direct access to nature view while indoors, suggesting water 
elements were less likely to be associated with the representation of nature.

Regarding the research questions; "How do the occupants feel around interior water elements?", "What is the relationship between interior water elements preferences and stress factors?", and "What are the differences in occupants' preferences for interior water elements according to gender?", briefly, it can be stated that, participants believed that, water elements as spatial elements were a good representation of nature in the built environment. Moreover, participants feel less stressed when they encounter water elements in interiors. Regarding preferences for water elements, females and males were very similar regarding the preference for water walls, fountains, and waterfalls, including fishponds and aquariums, as well as photographs of water, ocean view wallpapers, and waterthemed paintings.

It was found that biophilic design approaches may lead to improvements in the occupants' wellbeing, however, most participants stated they were most connected to nature when they had direct access to a view.

The main limitation of the study may be regarding the sample. The sample size is more than sufficient for a qualitative discussion, however, in order to conduct further quantitative analysis, it would be beneficial to ensure a more precise sample size and selection process, in terms of gender and occupational balance. Calculating the exact population size would allow a more robust sampling method, such as stratified sampling that might be more appropriate for a population with mixed characteristics. Despite this limitation, the results of this research provide a general outline for the effects on user well-being of interior water elements in the consideration of biophilic design approach. These points may be considered in further studies that may include larger sample sizes, as well as studies in other cultures. Overall, this study will provide a basis for further investigation into the positive effects of biophilic design approaches in educational environments, as well as spaces with various other functions. Furthermore, the findings contribute to theory and practice in the fields of interior architecture, biophilia, and biophilic design, and shed light on preferences for interior water elements. 


\section{REFERENCES}

- Abercrombie, N., Gatrell, T., \& Thomas, C. (1998). Universities and health in the twenty-first century. In A. D. Tsouros, G. Dowding, J. Thompson, \& M. Dooris (Eds.), Health promoting universities: Concept, experience and framework for action (Organizational Development: 21st Century Health Policy Health Promotion ed., pp. 33-39). World Health Organization.

- $\quad$ Alvarsson, J. J., Wiens, S., \& Nilsson, M. E. (2010). Stress Recovery during Exposure to Nature Sound and Environmental Noise. International Journal of Environmental Research and Public Health, 7(3), 1036-1046. https://doi.org/10.3390/ ijerph7031036

- $\quad$ Annerstedt, M., \& Währborg, P. (2011). Nature-assisted therapy: Systematic review of controlled and observational studies. Scandinavian Journal of Public Health, 39(4), 371-388. https://doi.org/10.1177/1403494810396400

- $\quad$ Baum, A., Singer, J. E., \& Baum, C. S. (1984). Stress and the environment. In G. W. Evans (Ed.), Environmental stress (First paperback edition ed., pp. 15-45). Cambridge University Press 1982.

- $\quad$ Bhat, R. H. (2015). Environmental stressors and its impact on human being. International Journal of Humanities and Social Sciences, 5(1), 37-40

- $\quad$ Bilir, A. (2019). Sanat yoluyla düşünme: Su örneği (Thinking through art: Water as an example). Anadolu Üniversitesi Sanat \& Tasartm Dergisi (Anadolu University Journal of Art and Design), 9(1), 116-127. https://doi.org/10.20488/ sanattasarim. 600433

- Bilotta, E., Vaid, U., \& Evans, G. W. (2019). Environmental stress. In L. Steg \& J. I. M. de Groot (Eds.), Environmental psychology: An introduction (Second edition, pp. 36-44). John Wiley \& Sons. https://doi.org/10.1002/9781119241072.ch4

- $\quad$ Browning, W., Ryan, C., \& Clancy, J. (2014). 14 patterns of biophilic design improving health and well-being in the built environment. Terrapin Bright Green.

- Byrne, J. A. (2011). Biophilia. In N. Cohen \& P. Robbins (Eds.), Green Cities: An A-to-Z Guide (The SAGE Reference Series on Green Society: Toward a Sustainable Future-Series Editor: Paul Robbins, 1st Edition, pp. 1-4). SAGE Publications. https://doi. org/10.1145/1179849.1179879

- $\quad$ Clouse, A. M. (2016). Human psychological response to and benefits of interior water features. The University of Southern Mississippi.

- $\quad$ Demirbaş, G. U. \& Demirbaş, Ö. O. (2019). Biyofilik Tasarım Kapsamında Peyzaj Mimarlı̆̆ı ve İç Mimarlık Arakesiti: Ĕ̆itim Programlarının Karşılıklı Değerlendirilmesi. Türkiye Peyzaj Araştırmaları Dergisi (Turkish Journal of Landscape Research), 2(2), 50-60.

- Düzenli, T., Alpak, E. M., \& Akyol, D. (2019). Peyzaj mimarliğinda su Öğesinin tarihsel süreçteki kullanim amaçlari (Purpose of water usage in landscape design in history). Anadolu Üniversitesi Sanat \& Tasarim Dergisi (Anadolu University Journal of Art \& Design), 9(1), 20-35. https://doi.org/10.20488/sanattasarim.599987

- Evans, G. W., \& Cohen, S. (1987). Environmental stress. In D. Stokols \& I. Altman (Eds.), Handbook of environmental psychology (Vol. 1, pp. 571-610). John Wiley \& Sons.

- Felsten, G. (2009). Where to take a study break on the college campus: An attention restoration theory perspective. Journal of Environmental Psychology, 29(1), 160-167. https://doi.org/10.1016/j.jenvp.2008.11.006

- $\quad$ Freihoefer, K., Guerin, D., Martin, C., Kim, H.-Y., \& Brigham, J. K. (2013). Occupants' satisfaction with, and physical readings of, thermal, acoustic, and lighting conditions of sustainable office workspaces. Indoor and Built Environment, 24(4), 457-472. https://doi.org/10.1177/1420326x13514595

- Heerwagen, J. H., \& Orians, G. H. (1986). Adaptations to Windowlessness. Environment and Behavior, 18(5), 623-639. https://doi.org/10.1177/0013916586185003

- Joye, Y. (2011). Biophilic design aesthetics in art and design education. The Journal of Aesthetic Education, 45(2), 17. https:// doi.org/10.5406/jaesteduc. 45.2 .0017

- Joye, Y., \& van den Berg, A. E. (2019). Restorative environments. In L. Steg \& J. I. M. de Groot (Eds.), Environmental psychology: An introduction (Second Edition, pp. 65-75). John Wiley \& Sons. https://doi.org/10.1002/9781119241072.ch7

- Kaplan, R., \& Kaplan, S. (1989). The experience of nature: A psychological perspective (1st Edition). Cambridge University Press. 
- $\quad$ Kellert, S. (2014). Biophilia and biomimicry: Evolutionary adaptation of human versus nonhuman nature. Intelligent Buildings International, 8(2), 51-56. https://doi.org/10.1080/17508975.2014.902802

- $\quad$ Kellert, S. R. (2005). Building for life: Designing and understanding the Human-Nature connection (2nd Edition). Island Press.

- $\quad$ Kellert, S. R., \& Calabrese, E. F. (2015). The practice of biophilic design. https://www.biophilic-design.com/

- $\quad$ Kellert, S. R., \& Wilson, E. O. (1993). The Biophilia hypothesis. Island Press.

- $\quad$ Kellert, S. R., Heerwagen, J., \& Mador, M. (2011). Biophilic design: The theory, science and practice of bringing buildings to life (1st Ed.). John Wiley \& Sons.

- Lange, E., \& Schaeffer, P. V. (2001). A comment on the market value of a room with a view. Landscape and Urban Planning, 55(2), 113-120. https://doi.org/10.1016/s0169-2046(01)00148-7

- $\quad$ Lau, S. S. Y., \& Yang, F. (2009). Introducing healing gardens into a compact university campus: Design natural space to create healthy and sustainable Ulrich, R. S.

- Landscape Research, 34(1), 55-81. https://doi.org/10.1080/01426390801981720

- Luttik, J. (2000). The value of trees, water and open space as reflected by house prices in the Netherlands. Landscape and Urban Planning, 48(3-4), 161-167. https://doi.org/10.1016/s0169-2046(00)00039-6

- $\quad$ Mangone, G., Capaldi, C. A., van Allen, Z. M., \& Luscuere, P. G. (2017). Bringing nature to work: Preferences and perceptions of constructed indoor and natural outdoor workspaces. Urban Forestry \& Urban Greening, 23, 1-12. https://doi.org/10.1016/j. ufug.2017.02.009

- $\quad \quad$ Najafi, N., Movahed, K., Barzegar, Z., \& Samani, S. (2018). Environmental factors affecting students' stress in the educational environment: A case study of Shiraz schools. International Journal of School Health, 5(2), 1-7. https://doi.org/10.5812/ intjsh.67153

- Nassar, U. A., \& El-Samaty, H. S. (2014). Transition space in higher education buildings as an efficient "Behavior setting" model. International Journal of Innovative Research in Science, Engineering and Technology, 3(1), 8304-8319.

- Rutkin, K. M. (2005). User preference of interior design elements in hotel lobby spaces (Master's thesis). The University of Florida.

- Steg, L., van den Berg, A. E., \& de Groot, J. I. M. (2019). Environmental psychology: History, scope, and methods. In L. Steg \& J. I. M. de Groot (Eds.), Environmental psychology: An introduction (Second edition, pp. 1-11). John Wiley \& Sons. https:// doi.org/10.1002/9781119241072.ch1

- Tanner, C. K. (2000). The influence of school architecture on academic achievement. Journal of Educational Administration, 38(4), 309-330. https://doi.org/10.1108/09578230010373598

- Tarakçı Eren, E., Düzenli, T. $\quad$ g., \& Akyol, D. (2018). Peyzaj mimarliğı Öğrencilerinin, Çevre tasarımında biyomorfik ve parametrik tasarım yaklaşımlarına karşı tutumları (Attitudes of landscape architecture students towards biomorphic and parametric design approaches in environmental design). Anadolu Üniversitesi Sanat \& Tasarım Dergisi (Anadolu University Journal of Art and Design), 8(1), 126-143. https://doi.org/10.20488/sanattasarim.510285

- Tennessen, C. M., \& Cimprich, B. (1995). Views to nature: Effects on attention. Journal of Environmental Psychology, 15(1), 77-85. https://doi.org/10.1016/0272-4944(95)90016-0

- Toyne, P., \& Khan, S. A. (1998). A common agenda? Health and the greening of higher education. In A. D. Tsouros, G. Dowding, J. Thompson, \& M. Dooris (Eds.), Health Promoting Universities: Concepts, Experience and Framework for Action (Organizational Development: 21st Century Health Policy Health Promotion ed., pp. 41-49). World Health Organization Regional Office for Europe Copenhagen.

- Triantis, E. (2005, May). Environmental strategies in retrofitting of educational buildings - the integrated approach. 709-714.

- Ulrich, R. (2008). Biophilic theory and research for healthcare design. In S. R. Kellert, J. Heerwagen, \& M. Mador, Biophilic Design: The Theory, Science and Practice of Bringing Buildings to Life (1st Edition, pp. 88-106). John Wiley \& Sons.

- Ulrich, R. S. (1979). Visual landscapes and psychological well-being. Landscape Research, 4(1), 17-23. https://doi. org/10.1080/01426397908705892

- (1986). Human responses to vegetation and landscapes. Landscape and Urban Planning, 13, 29-44. https://doi. org/10.1016/0169-2046(86)90005-8

- $\quad$ Ulrich, R. S. (1992). How design impacts wellness. The Healthcare Forum Journal, 35(5), $20-25$.

- Ulrich, R. S. (1993). Biophilia, biophobia, and natural landscapes. In S. R. Kellert \& E. O. Wilson, The Biophilia Hypothesis (pp. 74-137). Island Press. 
- Watchman, M., Demers, C. M. H., \& Potvin, A. (2020). Biophilic school architecture in cold climates. Indoor and Built Environment, 1420326X2090830. https://doi.org/10.1177/1420326x20908308

- Wells, N., \& Rollings, K. (2012). The natural environment: Influences on human health and function. In S. D. Clayton (Ed.), the Oxford Handbook of Environmental and Conservation Psychology (pp. 510-524). Oxford University Press.

- White, M., Smith, A., Humphryes, K., Pahl, S., Snelling, D., \& Depledge, M. (2010). Blue space: The importance of water for preference, affect, and restorativeness ratings of natural and built scenes. Journal of Environmental Psychology, 30(4), 482-493. https://doi.org/10.1016/j.jenvp.2010.04.004

- Wilson, E. O. (1984). Biophilia. Harvard University Press. 